\title{
Promising effects of silver tungstate microcrystals on fibroblast human cells and three dimensional collagen matrix models: A novel non-cytotoxic material to fight oral disease
}

\author{
Natali Lisette Haro Chávez ${ }^{\mathrm{a}, 1}$, Erica Dorigatti de Avila ${ }^{\mathrm{a}, *, 1}$, Paula Aboud Barbugli ${ }^{\mathrm{a}}$, \\ Regiane Cristina de Oliveira ${ }^{\mathrm{b}}$, Camila Cristina de Foggi ${ }^{\mathrm{a}}$, Elson Longo ${ }^{\mathrm{b}}$, Carlos Eduardo Vergani ${ }^{\mathrm{a}}$ \\ a Department of Dental Materials and Prosthodontics, School of Dentistry at Araraquara, São Paulo State University (UNESP), Rua Humaita, 1680, 14801-903, \\ Araraquara, SP, Brazil \\ ${ }^{\mathrm{b}}$ CDMF-UFSCar-Universidade Federal de São Carlos, Washington Luis km 235, P.O. Box 676, 13565-905, São Carlos, SP, Brazil
}

A R T I C L E I N F O

\section{Keywords:}

Cytotoxicity

Fibroblast

Microcrystals

Silver

\begin{abstract}
A B S T R A C T
Silver tungstate $\left(\alpha-\mathrm{Ag}_{2} \mathrm{WO}_{4}\right)$ microcrystals have shown encouraging results regarding their antimicrobial activity. However, in addition to the promising outcomes in fighting oral disease, cytotoxic tests are mandatory for screening new materials for biological applications. Here, we developed a better understanding of the effects of microcrystals on the behavior of both human gingival fibroblast (HGF) cells and three-dimensional (3D) collagen matrices. To perform these experiments, the lowest concentration of $\alpha-\mathrm{Ag}_{2} \mathrm{WO}_{4}$ capable of preventing the visible growth of Candida albicans (C. albicans) planktonic cells was defined as the test concentration, and it ranged from 0.781 (C1) to 7.81 (C2) to 78.1 (C3) $\mu \mathrm{g} / \mathrm{mL}$. Complete medium and lysis buffer (LB) served as negative $\left(\mathrm{C}^{-}\right.$) and positive $\left(\mathrm{C}^{+}\right)$controls, respectively. The effect of the microcrystal concentration on the morphology, remodeling and proliferation of HGF cells was evaluated by different approaches. Quantitative and qualitative assessments demonstrated that $\alpha-\mathrm{Ag}_{2} \mathrm{WO}_{4}$ did not affect the mitochondrial enzymatic activity of HGF cells cultured in a monolayer or the cell viability within 3D collagen matrices. These experiments showed that $\alpha-\mathrm{Ag}_{2} \mathrm{WO}_{4}$ at the $\mathrm{C} 2$ concentration did not damage the genomic DNA. The development of new materials is attractive for the possible treatment of diseases and for avoiding indiscriminate prescribing of antibiotics. These findings provide information on the effect of $\alpha-\mathrm{Ag}_{2} \mathrm{WO}_{4}$ on cell behavior and reveal that these microcrystals are non-cytotoxic against human gingival cells over a sufficient period to measure the hazard potential.
\end{abstract}

\section{Introduction}

The complex oral environment contains one of the most variable microbiota in the entire human body with more than 600 previously identified phylotypes [1]. An imbalance between commensal bacteria and fungi in the stable oral microbial is required to initiate oral infections. A disturbance in the oral ecosystem results from the presence of complex microbial communities attached to natural or artificial solid surfaces, combined with a complex set of local or systemic conditions, such as diabetes and hypertension, and environmental risk factors, such as poor dental hygiene, age, long-term medication use, and smoking [2-5]. The current therapies involve biofilm removal associated with local antimicrobial agents [6,7]. However, antimicrobial agents used to kill or inhibit the growth of microorganisms have been indiscriminately prescribed, thus provoking worldwide microbial resistance, which is one of the most concerning public health problems [8,9]. The risks associated with antimicrobial overuse threaten public health and may cause severe illness and increased mortality rates [10,11]. Invasive fungal infections, specifically triggered by the genus Candida, have been highlighted due to the involvement of these bacteria in the infections of hospitalized patients, which has caused an economic impact. According to the Centers for Disease Control and Prevention (CDC), Candida infections affect approximately 46,000 hospitalized patients in the United States per year, of whom $30 \%$ with drug-resistant Candida die during hospitalization [12]. Furthermore, resistant Candida infections may increase U.S. healthcare costs by millions of dollars each year. In an attempt to combat oral diseases and avoid infection progression, critical efforts have been made to implement new strategies against the potential use of medications.

The emerging field of nanotechnology includes the development of

\footnotetext{
* Corresponding author.

E-mail address: erica.fobusp@yahoo.com.br (E.D. de Avila).

${ }^{1}$ Authors contributed equally to the study.
} 
new materials at the nanoscale level that possess innumerable applications in the areas of technology and health [13]. Among the materials described in the relevant literature, silver has been widely accepted due to its broad-spectrum antimicrobial properties without promoting resistance and its low toxicity compared with that of other metals $[14,15]$. Silver ions can reacts with charges from microbial surfaces and interrupts the metabolic pathways of cells. Silver can also infiltrate into the infectious cell membrane and interrupt DNA replication $[16,17]$. Concomitant with these promising outcomes against microorganisms, the potential effect of silver on human cells, even at low concentrations, is still considered a critical concern. The capacity of silver to induce the apoptotic signaling genes of mammalian cells has encouraged the use of this metal for treating cancer and autoimmune diseases [18]. However, further investigations have revealed that the consequences of using silver nanoparticles (AgNPs) include potential changes in the cognitive, sensory, and motor functions, which result in brain and liver damage $[19,20]$. Hence, to optimize the antimicrobial properties of silver and to reduce the silver concentration, our team synthesized silver tungstate $\left(\alpha-\mathrm{Ag}_{2} \mathrm{WO}_{4}\right)$ microcrystals. The preliminary data showed encouraging results regarding the antimicrobial activity of $\alpha-\mathrm{Ag}_{2} \mathrm{WO}_{4}$ [21], but little is known about the cytotoxicity of these compounds. In this study, we first evaluated the influences of the minimum fungicide concentration (MFC) of microcrystals on the viability and morphology of human gingival fibroblast (HGF) cells cultured in a monolayer and in threedimensional (3D) collagen matrices. Next, to ensure a more comprehensive understanding of this novel material, we evaluated the $\alpha$ $\mathrm{Ag}_{2} \mathrm{WO}_{4}$ concentration-mediated reactive oxygen species (ROS) generation and confirmed their non-cytotoxicity according to the DNA integrity.

\section{Materials and methods}

\subsection{Preparation of microcrystals}

Silver tungstate microcrystals were prepared as previously described [22]. Briefly, $1 \mathrm{mmol}$ of sodium tungstate dihydrate $\left(\mathrm{Na}_{2} \mathrm{WO}_{4} \cdot 2 \mathrm{H}_{2} \mathrm{O} ; \geq 99.0 \%\right.$ purity, Sigma-Aldrich, St. Louis, MO, USA) and $2 \mathrm{mmol}$ of silver nitrate $\left(\mathrm{AgNO}_{3} ; 99.8 \%\right.$ purity, Sigma-Aldrich, St. Louis, MO, USA) were separately dissolved in $50 \mathrm{~mL}$ of deionized water and were identified as solutions 1 and 2, respectively. Solution 2 was gently added to solution 1 under vigorous mechanical stirring, and the new mixture was heated to $90^{\circ} \mathrm{C}$ for $10 \mathrm{~min}$. After centrifugation, the precipitate was washed with deionized water and ethanol, and the particles were dehydrated in a drying oven at $60^{\circ} \mathrm{C}$ for $12 \mathrm{~h}$. The final concentration of the compound was adjusted in deionized water to $2 \mathrm{mg} / \mathrm{mL}$, and the sample was stored in the dark at room temperature until further use.

\subsection{Physicochemical assessment and silver concentration}

The crystal structure of the $\alpha-\mathrm{Ag}_{2} \mathrm{WO}_{4}$ microcrystals were characterized by X-ray diffraction (XRD) using a Rigaku-DMax/2500PC (Japan) diffractometer, with $\mathrm{Cu} \mathrm{K \alpha}$ radiation $(\lambda=1.5406 \AA)$ in the $2 \theta$ range of $10^{\circ}-70^{\circ}$ at a scanning rate of $2^{\circ} / \mathrm{min}$. The identification procedures followed the standard as defined by the Joint Committee on the Inorganic Crystal Structure Database (ICSD) card no. 416525 [23,24]. The microcrystal morphology aspects were also examined using field emission scanning electron microscopy (FE-SEM) (Supra 35-VP Carl Zeiss, Germany) operated at $15 \mathrm{kV}$. The combination of transmission electron microscopy (TEM) at $200 \mathrm{kV}$, with energy-dispersive X-ray spectroscopy (EDS) (FEI Tecnai G2 F20, Hillsboro, OR, USA) detector was employed in order to identify silver particles on the $\alpha-\mathrm{Ag}_{2} \mathrm{WO}_{4}$ microcrystal surfaces. Furthermore, to measure the size distribution of $\alpha-\mathrm{Ag}_{2} \mathrm{WO}_{4}$, representative SEM images containing 100 microcrystals were exported to ImageJ 1.51 (National Institutes of Health, USA). Then, the width and length of each microcrystal were calculated and the data plotted as mean and standard deviation (SD). The microcrystal synthesis process triggers the oxidation of silver into $\alpha-\mathrm{Ag}_{2} \mathrm{WO}_{4}$. The oxidized silver $\left[\mathrm{Ag}^{+}\right]$concentration in the microcrystal structure was calculated using the following equation: Silver content in the MFC of $\alpha$ $\mathrm{Ag}_{2} \mathrm{WO}_{4}$ microcrystals $=$ MFC of $\alpha-\mathrm{Ag}_{2} \mathrm{WO}_{4}$ microcrystals $(\mu \mathrm{mol} /$ $\mathrm{mL}) \times 10^{-6} /$ Molecular Weight of each chemical element in the molecular structure of $\alpha-\mathrm{Ag}_{2} \mathrm{WO}_{4}$ [25].

\subsection{Microcrystal concentration against Candida albicans}

The experimental groups were established according to the MFC obtained from Candida albicans (C. albicans) ATCC 90028. Previously published MFC data were used to determine the lowest concentration capable of killing $100 \%$ of fungi, and this value was $7.81 \mu \mathrm{g} / \mathrm{mL}$ (C2) [25]. Further concentrations were used as experimental references: 10 times diluted (C1) and 10 times concentrated (C3). The cells incubated with lysis buffer (LB) served as positive controls, representing 100\% cell death. Additionally, untreated cells were incubated with sterile medium to serve as background controls. Working solutions were prepared immediately before use by diluting the appropriate amount of $\alpha-\mathrm{Ag}_{2} \mathrm{WO}_{4}$ adjusted in deionized water in Dulbecco's modified Eagle's medium (DMEM).

\subsection{In vitro fibroblast cell culture and growth conditions}

HGF cells (Rio de Janeiro Cell Bank Code 0089) were cultured in low-glucose DMEM (Sigma Chemical Co., St. Louis, MO, USA) supplemented with $10 \%$ fetal bovine serum (FBS, Gibco, Grand Island, NY, USA), $100 \mathrm{IU} / \mathrm{mL}$ penicillin, $100 \mathrm{mg} / \mathrm{mL}$ streptomycin (Sigma-Aldrich, St. Louis, MO, USA), and $2 \mathrm{mM}$ L-glutamine (Gibco, Grand Island, NY, USA) in a humidified atmosphere containing $5 \% \mathrm{CO}_{2}$ at $37^{\circ} \mathrm{C}$. HGF cells between passages 3 and 8 were used for all experiments. After reaching $90 \%$ confluence, the cells were washed with phosphate-buffered saline (PBS), recovered using trypsin and resuspended in fresh medium prior to further analyses.

\subsection{Proliferation assay of the microcrystals and cells}

An assessment of the microcrystal effects on the metabolic mitochondrial activity of the cells was performed by an alamarBlue assay. HGF cells were seeded at $8 \times 10^{3}$ cells/well directly onto 96-well polystyrene black plates (TPP ${ }^{\circ}$ tissue culture plates, St. Louis, MO USA) for the monolayer cell culture. The cells were statically incubated at $37^{\circ} \mathrm{C}$ under $5 \% \mathrm{CO}_{2}$ conditions for $24 \mathrm{~h}$. Subsequently, the medium was removed, and $200 \mu \mathrm{L}$ of fresh medium containing $\mathrm{Ag}_{2} \mathrm{WO}_{4}$ microcrystals was added at the three different concentrations. Next, $10 \%$ alamarBlue (Invitrogen, Carlsbad, CA, USA) was added to each well, and the fluorescence signals were measured using a Fluoroskan (Fluoroskan Ascent FL; Thermo Scientific; Waltham, MA USA) at an excitation wavelength of $544 \mathrm{~nm}$ and an emission wavelength of $590 \mathrm{~nm}$ after $24 \mathrm{~h}$ of incubation. The experiment was performed in quintuplicate and with three independent biological repetitions.

\subsection{SEM morphological analysis}

To confirm the impact of the microcrystals on cell behavior, the fibroblast morphology was examined by SEM after a 24-h incubation with $\alpha-\mathrm{Ag}_{2} \mathrm{WO}_{4}$. For the pre-incubation procedure, $500 \mu \mathrm{L}$ aliquots of $5 \times 10^{4}$ cells were dispensed onto sterile cover glass slides on a 24-well plate (TPP tissue culture, Switzerland) and maintained at $37^{\circ} \mathrm{C}$ under $5 \% \mathrm{CO}_{2}$ conditions. At $24 \mathrm{~h}$ after monolayer formation, the medium was removed, and $\alpha-\mathrm{Ag}_{2} \mathrm{WO}_{4}$ microcrystals were added to each well at the respective concentrations. After the cells had been exposed to the material for $24 \mathrm{~h}$, the samples were prepared for SEM analyses. The fixation step was performed by incubating the samples in a solution of $2.5 \%$ glutaraldehyde ( $\mathrm{pH}$ 7.4) at room temperature for $1 \mathrm{~h}$. The PBS-washed 
slides were then subjected to standard procedures for dehydrating the specimens in which $70 \%$ and $90 \%$ ethanol were used for $1 \mathrm{~h}$ per step, ending with 5 changes of $100 \%$ ethanol within $30 \mathrm{~min}$. Prior to visualization, the slides were placed under vacuum to ensure that the samples were free of moisture, and after 7 days of storage, the slides were sputter coated with gold. Images at different magnifications $(\times 100$ and $\times 250$ ) were obtained from different areas of the slides with SEM (JEOL JSM-6610LV). For SEM analysis, the experiment was performed in duplicate for each experimental and control group.

\subsection{Modulation of ROS production in fibroblast cells}

The ROS production estimate in HGF cells was performed according to the following design. HGF cells were seeded at $8 \times 10^{3}$ cells $/ \mathrm{mL}$ onto 96-well black plates and incubated for $24 \mathrm{~h}$ in supplemented medium for monolayer cell culture. On the next day, the medium was removed, and the microcrystal solutions were added at their respective concentrations with $100 \mu \mathrm{L}$ of Krebs-Henseleit buffer $[\mathrm{pH} 7.35(\mathrm{NaCl}$ $140 \mathrm{mmol} \mathrm{L}^{-1}$, KCL $\left.3.0 \mathrm{mmol} \mathrm{L}^{-1}\right)$ ]. Finally, $2 \mu \mathrm{L}$ of fluorescent probe [2,7-dichlorodihydrofluorescein (DCFH), Thermo Scientific, USA) was added to each well to measure the intracellular oxidative stress at the time points of 1, 10, 20, 30, 90, 150 and 240 min. Quantitative measurements of ROS generation were performed by a Fluoroskan spectrofluorimeter with excitation and emission wavelengths of 485 and $530 \mathrm{~nm}$, respectively. The experiment was performed in duplicate with four biological replicates. Concomitantly, cells from the same culture were grown on a 96-well white plate for qualitative fluorescence intensity assessment. The DCFH probe penetrates the cells and produces DCFH carboxylate anions as it undergoes hydrolysis. The oxidation of DCFH only generates intracellular fluorescence by integrated cells $[26,27]$. Standard controls, as represented by cells without microcrystals and incubated with lysis buffer, were used for the same experiment, thus ensuring the reliability of the data.

\subsection{Integrity of genomic DNA}

To investigate whether $\alpha-\mathrm{Ag}_{2} \mathrm{WO}_{4}$ microcrystals induce DNA degradation in HFG cells, the cells were incubated with $\alpha-\mathrm{Ag}_{2} \mathrm{WO}_{4}$, and the integrity of isolated DNA was confirmed by electrophoresis on a $1.0 \%$ agarose gel. Initially, HFG cells were cultured at $5 \times 10^{5}$ cells/ well in a 12 -well plate under $5 \% \mathrm{CO}_{2}$ at $37{ }^{\circ} \mathrm{C}$ for $24 \mathrm{~h}$. Subsequently, the microcrystals were added at the desired concentration (C2) with $1.5 \mathrm{~mL}$ of fresh medium, and the plate was incubated for $24 \mathrm{~h}$ under pre-established cell conditions before the analyses. The cells were harvested from polystyrene well surfaces through manual and gentle scraping with a plastic pipette tip into $150 \mu \mathrm{L}$ of PBS and then transferred to 1.5-mL Eppendorf tubes. DNA isolation was performed using a MasterPure $^{\mathrm{TM}}$ DNA Purification kit (EPICENTRE). The overall cell concentration was determined with a Nanodrop 2000 (Thermo Scientific), and approximately $100 \mathrm{ng} / \mu \mathrm{L}$ of individual samples was carefully loaded into each well for $1 \mathrm{~h}$ at room temperature using a fixed voltage of $60 \mathrm{~V}$. DNA bands were visualized and recorded under UV light with an Imager Gel Documentation System (Bio-Rad Laboratories). Negative and positive controls were included in the experiment. The experiment was performed in duplicate with two independent repetitions.

\subsection{In vitro $3 D$ collagen system}

HGF cells were propagated as previously described (see Section 2.3). Briefly, a collagen solution was prepared by mixing $4.6 \mathrm{~mL}$ of DMEM, $0.9 \mathrm{~mL}$ of FBS, $3.0 \mathrm{~mL}$ of type-I collagen extracted from rat tail ( $3 \mathrm{mg} / \mathrm{mL}), 0.5 \mathrm{~mL}$ of sodium hydroxide $(\mathrm{NaOH})$ and $1 \mathrm{~mL}$ of $3 \times 10^{5}$ cells $/ \mathrm{mL}$, mandatorily following this order, in a final volume of $10 \mathrm{~mL}$. In the experimental groups, the microcrystals were added to the collagen solution prior to gelation at the respective concentrations: C1, C2 and C3. Five milliliters of each solution was transferred to a 6-well plate, and the cell culture system was incubated for $20 \mathrm{~min}$ at $37^{\circ} \mathrm{C}$ with $5 \% \mathrm{CO}_{2}$ for gel polymerization. The medium was replaced every $48 \mathrm{~h}$, and the plate was re-incubated. To examine the changes in collagen gel diameter, the contraction index was measured at 24 and $96 \mathrm{~h}$ by using a universal caliper [3]. Collagen matrices were prepared without microcrystals and in the presence of lysis buffer, representing negative and positive controls, respectively.

\subsection{0. $3 D$ collagen cell morphology and viability}

For each independent experiment, the cell morphology was analyzed and recorded by a bright-field microscope (Leica DMI3000B) prior to the viability assessment, at $96 \mathrm{~h}$ after incubation. Cell viability was assessed by the MTT tetrazolium [3-(4,5-dimethylthiazol-2-yl) 2,5diphenyltetrazolium bromide] reduction assay. Following the exposure period, the collagen matrices were washed three times with PBS and incubated with $4 \mathrm{~mL}$ of MTT $(1 \mathrm{mg} / \mathrm{mL})$ at $37{ }^{\circ} \mathrm{C}$ under $5 \% \mathrm{CO}_{2}$ atmosphere for $4 \mathrm{~h}$. The MTT was then aspirated, and each collagen matrix was transferred to a $15-\mathrm{mL}$ tube containing $2 \mathrm{~mL}$ of isopropanol. The homogenization solution in each tube was vortexed for 2 min to ensure the complete dissolution of formazan crystals. Two hundred fifty microliters of supernatant was then transferred to a 96-well plate, and the colorimetric absorbance from the formazan dye concentration was determined by a spectrophotometer (EZ-Read-400E, Imp Exp LTDA, SP, Brazil) at a wavelength of $562 \mathrm{~nm}$. The data obtained from the experimental concentrations were plotted and compared to the controls. Three independent experiments were performed in duplicate.

\subsection{Fibroblast cell labeling and confocal laser scanning microscopy analyses}

The viability of HGF cells growing within a 3D collagen matrix was evaluated by a staining method to distinguish viable and non-viable cells. Initially, a stock solution was prepared by the dilution of $5 \mathrm{mM}$ carboxyfluorescein diacetate succinimidyl ester (CFSE - Cell Proliferation Kit, No. C-34554, Life Technology, CA, USA) in DMSO, according to the manufacturer's instructions. HGF cells were cultured as previously described (see Section 2.4). After detaching the cells with trypsin, HGF cells were re-suspended in PBS at $3 \times 10^{5}$ cells $/ \mathrm{mL}$. The $5 \mathrm{mM}$ CFSE solution was quickly added to thoroughly resuspend the cells, and the cells were incubated for $20 \mathrm{~min}$ at $37^{\circ} \mathrm{C}$ to reduce the autofluorescence. Stained cells were then washed twice with PBS buffer containing $2 \%$ FBS to suppress any dye remaining in the solution and resuspended in fresh DMEM at the same density $\left(3 \times 10^{5}\right.$ cells $\left./ \mathrm{mL}\right)$ before they were added to the collagen solution, according to a previously described experimental sequence (see Section 2.9). After 24 and $96 \mathrm{~h}$, the DMEM was removed, and the gels were maintained with propidium iodide (PI) at $0.06 \mathrm{mM}$ diluted in PBS for $15 \mathrm{~min}$ prior to fluorescence analyses. The effect of the microcrystals on the viability of cells cultured on collagen matrices was examined by confocal microscopy (Zeiss LSM 800, Jena, Germany). The green fluorescence of CFSE and the red color of PI were examined at 488 and $561 \mathrm{~nm}$, respectively, to reveal the distribution of live/dead cells. Images acquired through 10x Plan NeoFluar NA 0.3 air/dry objective lens were used for 3D reconstruction. The reliability of the data was confirmed by biological replication in two independent experiments.

\subsection{Data presentation and statistical analyses}

All data are presented as the mean \pm standard deviation. The dataset of each independent variable was evaluated for distribution (adherence to normal curve) and homoscedasticity. Since all variables mentioned above are continuously quantitative, for the data set with a normal distribution and homoscedasticity, a variance analysis method (ANOVA) was used with Tukey's post hoc test using GraphPad Prism version 5.0c, and $\mathrm{p}<0.05$ was considered statistically significant. 

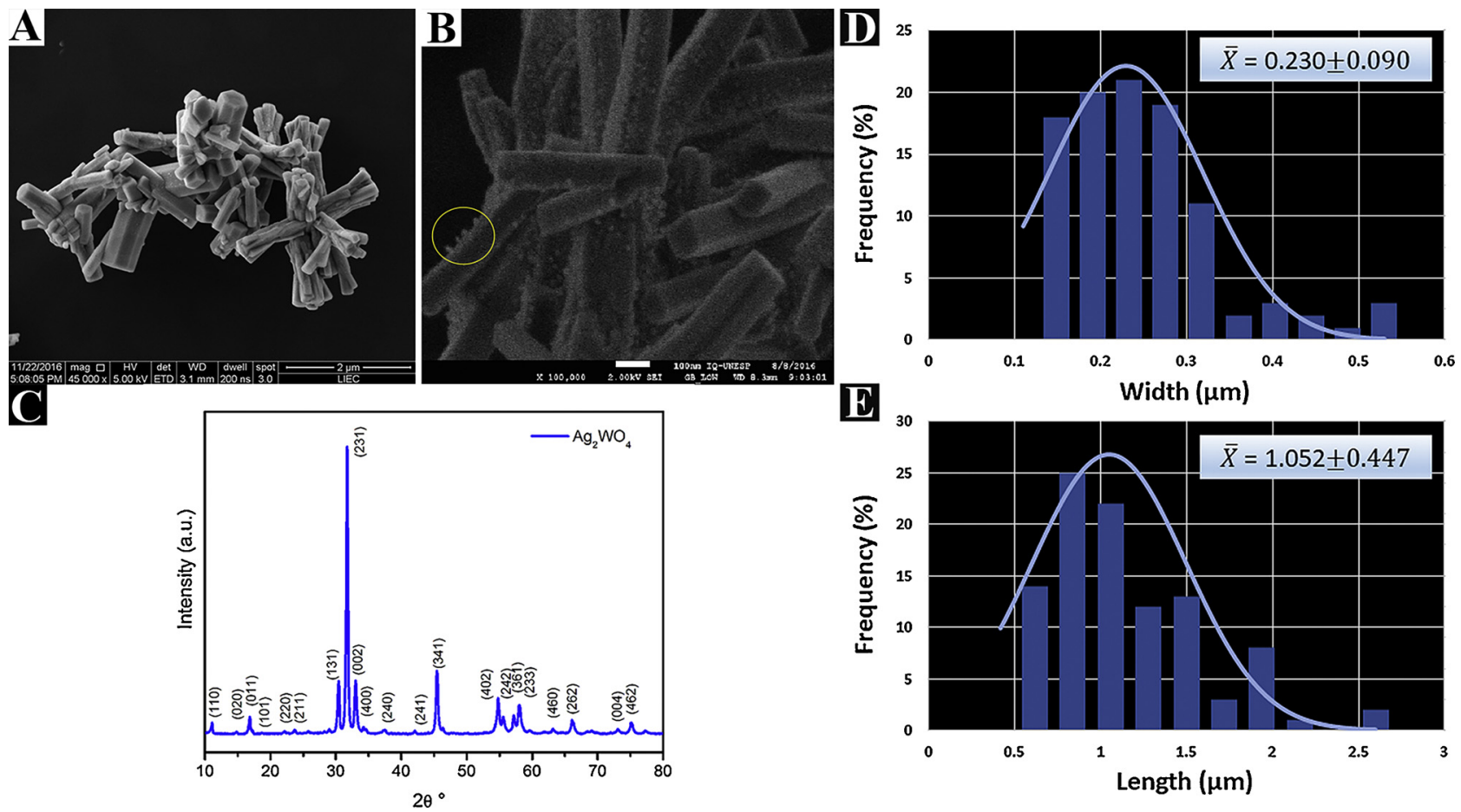

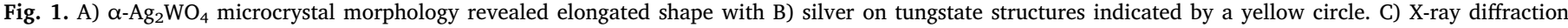

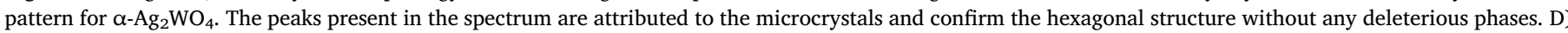

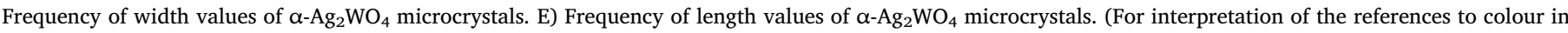
this figure legend, the reader is referred to the web version of this article.)

\section{Results}

\subsection{Silver tungstate microcrystal characterization and silver concentration}

Prior to the biological assessment, $\alpha-\mathrm{Ag}_{2} \mathrm{WO}_{4}$ microcrystals were characterized through SEM (Fig. 1A-B) and XRD (Fig. 1C). The microcrystals presented hexagonal, long structures with silver particles (Fig. 1B - circle colored yellow) measuring approximately $100 \mathrm{~nm}$. TEM combined with EDS mapping was performed to enable a local elemental analysis on each individual microcrystal and confirmed the presence of silver particles on the $\alpha-\mathrm{Ag}_{2} \mathrm{WO}_{4}$ surface. The relevant microcrystal structure is shown in Fig. S1 and the chemical mapping revealed that the $\alpha-\mathrm{Ag}_{2} \mathrm{WO}_{4}$ is composed of $\mathrm{Ag}, \mathrm{W}$ and $\mathrm{O}$ (Region 1), and silver particles are identified on microcrystal surface (Region 2) (Fig. S1). The XRD patterns revealed that all the diffraction peaks of $\alpha-\mathrm{Ag}_{2} \mathrm{WO}_{4}$ microcrystals could be indexed to the orthorhombic structure without the presence of secondary phases. The relative intensities and sharp diffraction peaks indicated that the $\alpha-\mathrm{Ag}_{2} \mathrm{WO}_{4}$ microcrystals were well crystallized, suggesting a long-range ordered structure. With regard to the microcrystals size distribution, the average values of width (Fig. 1D) and length (Fig. 1E) were $0.23 \mu \mathrm{m}(0.09)$ and $1.05 \mu \mathrm{m}$ (0.447), respectively.

To calculate the total $\left[\mathrm{Ag}^{+}\right]$concentration found in the $\alpha-\mathrm{Ag}_{2} \mathrm{WO}_{4}$ microcrystals we first converted our target concentration from $\mu \mathrm{g} / \mathrm{mL}$ to $\mu \mathrm{mol} / \mathrm{mL}$ :

$(7.81 \mu \mathrm{g} / \mathrm{mL}) /\left(463.6 \mathrm{~g} \mathrm{~mol}^{-1}\right) \mathrm{mL}$ of $\alpha-\mathrm{Ag}_{2} \mathrm{WO}_{4}=0.0168 \mu \mathrm{mol} / \mathrm{mL}$ of $\alpha-\mathrm{Ag}_{2} \mathrm{WO}_{4}$,

Based on the classical chemical definition, $1 \mathrm{~mol}$ of $\alpha-\mathrm{Ag}_{2} \mathrm{WO}_{4}$ releases $2 \mathrm{~mol}$ of $\mathrm{Ag}^{+}$, according to the following equation:

$\mathrm{Ag}_{2} \mathrm{WO}_{4} \rightarrow 2 \mathrm{Ag}^{+}+1 \mathrm{WO}_{4}^{-}$

Therefore, the molar concentration of $\mathrm{Ag}^{+}$is twice the concentration of $\alpha-\mathrm{Ag}_{2} \mathrm{WO}_{4}$, which means that the total $\left[\mathrm{Ag}^{+}\right]$concentration found in the $\alpha-\mathrm{Ag}_{2} \mathrm{WO}_{4}$ microcrystals was approximately $0.033 \mu \mathrm{mol} / \mathrm{mL}$.

\subsection{Effect of silver tungstate microcrystals on fibroblast cell proliferation and morphology}

The effect of $\alpha-\mathrm{Ag}_{2} \mathrm{WO}_{4}$ microcrystals on fibroblast cells was evaluated after $24 \mathrm{~h}$ of incubation. A quantitative colorimetric assay revealed no statistically significant difference in cell proliferation between the desired concentration $(p=0.085)$ and the negative control ( $\mathrm{p}=0.41$ ). A cytotoxic effect was observed when the fibroblast cells were exposed to $\alpha-\mathrm{Ag}_{2} \mathrm{WO}_{4}$ at $78.1 \mu \mathrm{g} / \mathrm{mL}$. At this concentration, the microcrystals affected the cell metabolism, displaying a dead cell population of approximately $100 \%$ at a time point sufficient to determine the degree of cytotoxicity (Fig. 2). In a healthy environment, fibroblast cells exhibited elongated and integrated shapes, with a dispersed appearance and attachment to the substrate. Further qualitative analyses by SEM and fluorescence microscopy of the cell morphology confirmed normal morphological features at $7.81 \mu \mathrm{g} / \mathrm{mL} \alpha-\mathrm{Ag}_{2} \mathrm{WO}_{4}$. At the highest concentration (C3), $\alpha-\mathrm{Ag}_{2} \mathrm{WO}_{4}$ caused complete cell death with membrane disruption, closely resembling the positive control (Fig. 3).

\subsection{Effect of silver tungstate microcrystals on $3 D$ collagen matrices}

Next, to investigate whether the microcrystals affected the ability of the $3 \mathrm{D}$ matrices to respond, $\alpha-\mathrm{Ag}_{2} \mathrm{WO}_{4}$ was suspended within the collagen solution prior to its polymerization. After the first $24 \mathrm{~h}, \mathrm{C} 2 \mathrm{de}-$ monstrated a slight interference of the function of fibroblasts to contract collagen matrices compared with the negative control and $\mathrm{C} 1$. However, HGF cells showed activity since the contraction index was significantly different from those of C3 and the control in which cell death occurred. When the fibroblast cells are dead, no stimulant can induce the fibroblast-collagen contraction, as in case of C3 and LB (Fig. 4). The mitochondrial activity of the HGF cells was evaluated by the MTT assay. After $96 \mathrm{~h}$ of incubation, no significant effect on cell viability was observed for $\alpha-\mathrm{Ag}_{2} \mathrm{WO}_{4}$ concentrations equal to or below 

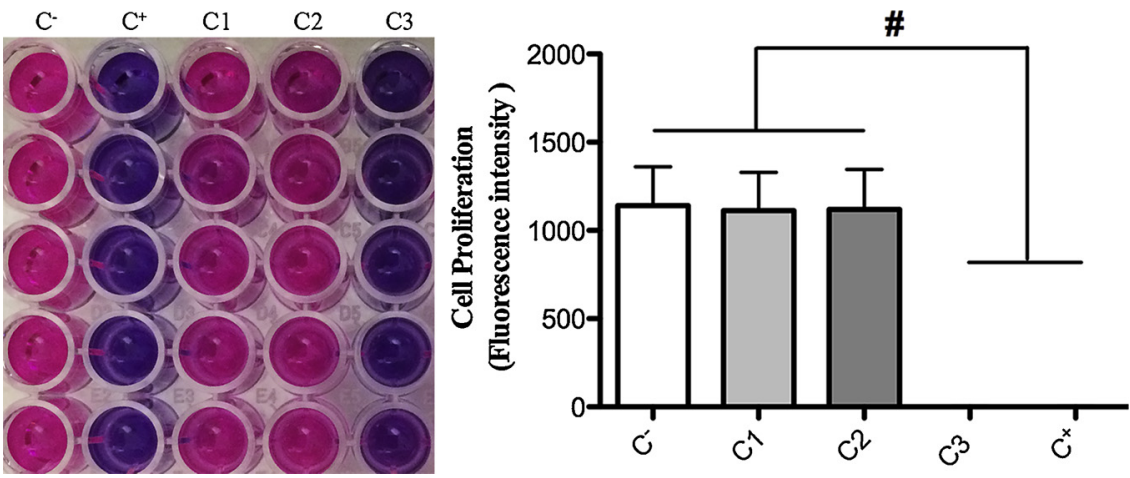

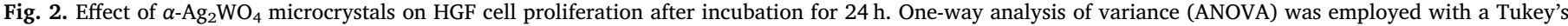
post hoc test using Graph-Pad Prism version 5.0c. Data are shown as the mean \pm SD $(n=15)$, and *p $<0.05$ was considered statistically significant.

$7.8 \mu \mathrm{g} / \mathrm{mL}(\mathrm{p}<0.5)$. Otherwise, based on this methodology, a substantial reduction was measured for cells exposed to C3 or LB, with cell metabolism decreased by more than $60 \%$ compared with that of the negative control (Fig. 5).

HGF cell proliferation within 3D collagen matrices was also confirmed by confocal microscopy analyses. An obvious similarity in the overall live cells was evident according to the microcrystals at the $\mathrm{C} 1$ and $\mathrm{C} 2$ concentrations compared to the control for both time points (Fig. 6). Dead cells were identified at the highest concentration (C3) by red fluorescence after PI counterstaining (yellow arrows in the figure).

\subsection{Effect of non-specific ROS production and cell damage}

Since the effect of oxidative stress on cellular response depends on the strength and duration of hazardous exposure, the non-specific ROS production from treated and untreated cells at different time points was measured. The outcomes remarkably demonstrated a natural generation of ROS in cells incubated with microcrystals at the lowest (C1) concentration and at the MFC (C2), with no significant difference between these treatments and the negative control. The extent of ROS levels was dependent on the increased $\alpha-\mathrm{Ag}_{2} \mathrm{WO}_{4}$ concentration over time. After $20 \mathrm{~min}$, the cells incubated with $78.1 \mu \mathrm{g} / \mathrm{mL}$ of $\alpha-\mathrm{Ag}_{2} \mathrm{WO}_{4}$ released significant ROS levels compared to the untreated cells. This effect remained over all the experimental periods analyzed (Fig. 7A). To confirm whether the overproduction of ROS induced by microcrystals provokes cellular death, concomitant to quantitative fluorometric detection, we compared the intensity of fluorescence between the concentrations studied with that of the control. No fluorescence was observed from the C3-treated cells after $20 \mathrm{~min}$ by using previously

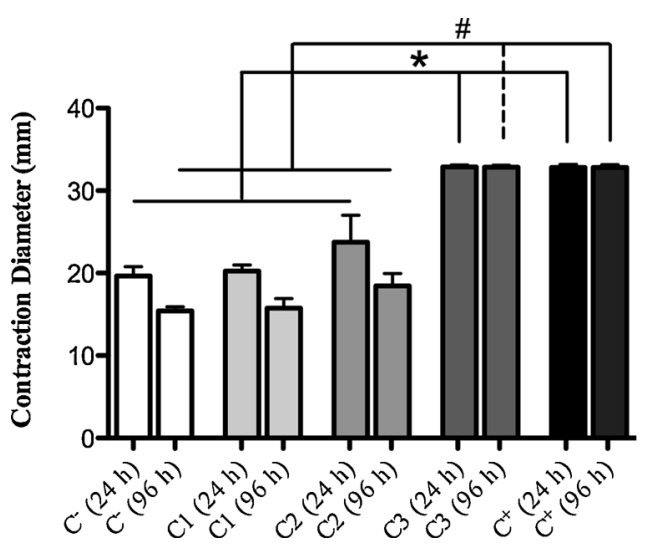

Fig. 4. Effect of $\alpha-\mathrm{Ag}_{2} \mathrm{WO}_{4}$ microcrystals on fibroblast-collagen contraction after incubation for 24 and $96 \mathrm{~h}$. The Kruskal-Wallis test was employed with a Dunn's Multiple Comparison Test using Graph-Pad Prism version 5.0c. Data are shown as the mean \pm SD $(n=6)$, and * $p<0.05$ was considered statistically significant.

established excitation and emission wavelengths. For C1 and C2, the intensity of fluorescence generated from the cells was similar to that of the negative control over time (Fig. 7B).

\subsection{Effect of silver tungstate microcrystals on DNA integrity}

Next, based on the knowledge acquired thus far, we evaluated the potential of $\alpha-\mathrm{Ag}_{2} \mathrm{WO}_{4}$ to affect the integrity and induce the
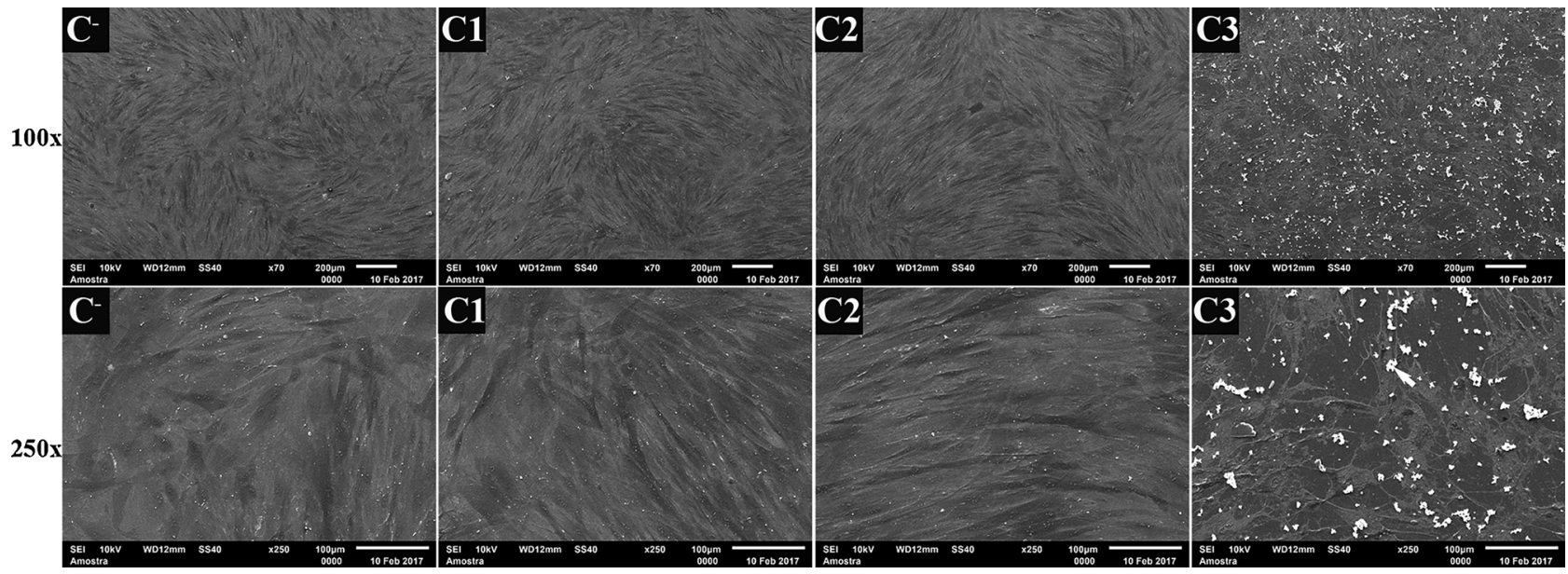

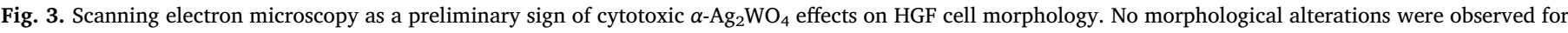
cells in direct contact with the $\mathrm{C} 1$ and $\mathrm{C} 2$ concentrations of the microcrystals. 

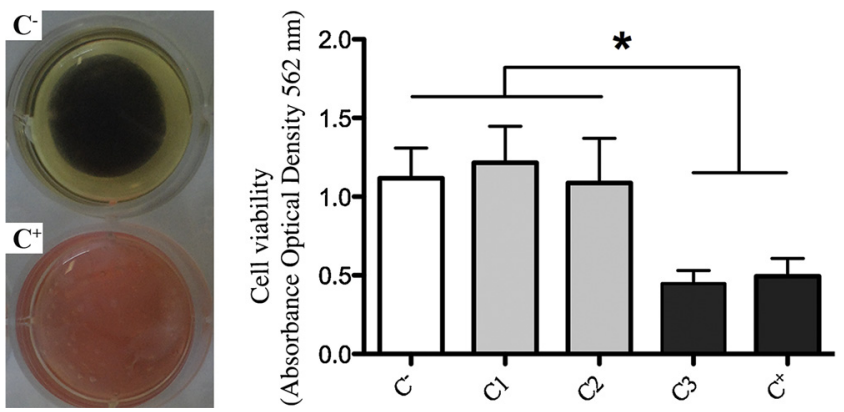

Fig. 5. Effect of $\alpha-\mathrm{Ag}_{2} \mathrm{WO}_{4}$ microcrystals on HGF cell viability within the collagen network. One-way analysis of variance (ANOVA) was employed with a Tukey's post hoc test using Graph-Pad Prism version 5.0c. Data are shown as the mean \pm SD $(n=6)$, and ${ }^{*} \mathrm{p}<0.05$ was considered statistically significant.

degradation of DNA. Following $24 \mathrm{~h}$ of exposure, intact and flat DNA bands (red arrows) were observed relative to the negative control and $\alpha-\mathrm{Ag}_{2} \mathrm{WO}_{4}$ at the $\mathrm{C} 2$ concentration, indicating that the microcrystals and their products did not affect the genomic DNA. However, the cytotoxicity of $\mathrm{C}^{+}$to fibroblast cells is clearly demonstrated in Fig. 8. The presence of several bands (black arrow) represented the degradation of DNA isolated from cells incubated with $\alpha-\mathrm{Ag}_{2} \mathrm{WO}_{4}$ at $78.1 \mu \mathrm{g} / \mathrm{mL}$.

\section{Discussion}

The search for new materials to fight oral disease and avoid the indiscriminate use of antibiotics [28-30] has triggered great efforts to obtain a better understanding of the potential health risks associated with exposure to these compounds. Silver tungstate microcrystals have previously been used to determine the antimicrobial effects against important fungi associated with a range of infections [21]. However, for its antimicrobial properties, a non-toxicity assessment is another essential consideration to determine the biomedical application of silver tungstate microcrystals. To date, the influences of $\alpha-\mathrm{Ag}_{2} \mathrm{WO}_{4}$ on eukaryotic cells remain an important issue to study. Herein, we demonstrated, for the first time, the biological safety aspects of silver tungstate microcrystals when they are in direct contact with gingival fibroblast cells. The assessments used in this study revealed that even with longterm exposure, the microcrystals did not affect the cell viability and morphology.

The ability of $\alpha-\mathrm{Ag}_{2} \mathrm{WO}_{4}$ in fighting $C$. albicans is related to the imperfect and crystalline patterns of atom arrangements in its orthorhombic structure and good photocatalytic capacity under visible light [25]. As known, $\alpha-\mathrm{Ag}_{2} \mathrm{WO}_{4}$ microcrystals consist of octahedral [ $\left.\mathrm{WO}_{6}\right]$, deltahedral $\left[\mathrm{AgO}_{7}\right]$, octahedral $\left[\mathrm{AgO}_{6}\right]$, tetrahedral $\left[\mathrm{AgO}_{4}\right]$, and angular $\left[\mathrm{AgO}_{2}\right]$ clusters connected by weak interactions. As a result of this energetically unstable microcrystal structure, $\mathrm{O}, \mathrm{W}$, and $\mathrm{Ag}$ atoms can vary their position and create distortion in the $\mathrm{Ag}-\mathrm{O}$ and $\mathrm{W}-\mathrm{O}$ bonds $[31,32]$. The polarized electric field of AWO will lead to the variation of cluster electronic density and the energy band structure, producing oxidizing radicals, such as $\mathrm{OH}^{*}$ and $\mathrm{O}_{2} \mathrm{H}^{*}$. The highly reactive free radical can interact irreversibly with organic compounds of the cells, causing collapse of the membranes and damage DNA, RNA and proteins of intracellular microorganism system. Thus, the consequent morphological breakdown in the microorganism's cells leads them to the death $[33,34]$.

Concomitantly, silver ions can bind onto the microbial cell membrane and relay signaling to block the mitochondrial respiratory function [35]. Since silver exhibits strong antimicrobial activity, we developed microcrystals as carrier of silver-based materials [31,36-38] in an attempt to reduce the concentration of silver ions in biological fluid, which appears to be oxidized while maintaining its desired properties. Interestingly, the potential antimicrobial effect of oxidized silver persisted, even at a significantly low concentration of $0.033 \mu \mathrm{mol} / \mathrm{mL}$, thus confirming that the radicals produced by the interaction of chemical elements in microcrystals play an important role in chemical reactions to kill C. albicans [25].

During the natural cellular respiration, adenosine triphosphate (ATP) is synthesized inside mitochondria by reduction of molecular $\mathrm{O}_{2}$ to water through a successive transfer of single electrons and coupled proton reactions [41]. As a natural byproduct of the normal metabolism of cells, a small percentage of non-reduced oxygen exhibits superoxide anion and other oxygen-containing radicals. However, the type of ROS produced and its concentration can play an important role in cellular signaling systems or induce damage [41-43]. The presence of metals can also participate in one-electron oxidation-reduction reactions and leading to the formation of ROS [44]. The effect of ROS in cell function involves oxidative modification of proteins [45], free radical-mediated lipid peroxidation [46,47], DNA-strand breaks, modulation of gene expression [48] and modulation of inflammatory response [49], which can lead cell death or mutation. Silver is considered an important protagonist against microorganisms, but it also possesses malignant properties against human cells, depending on its concentration

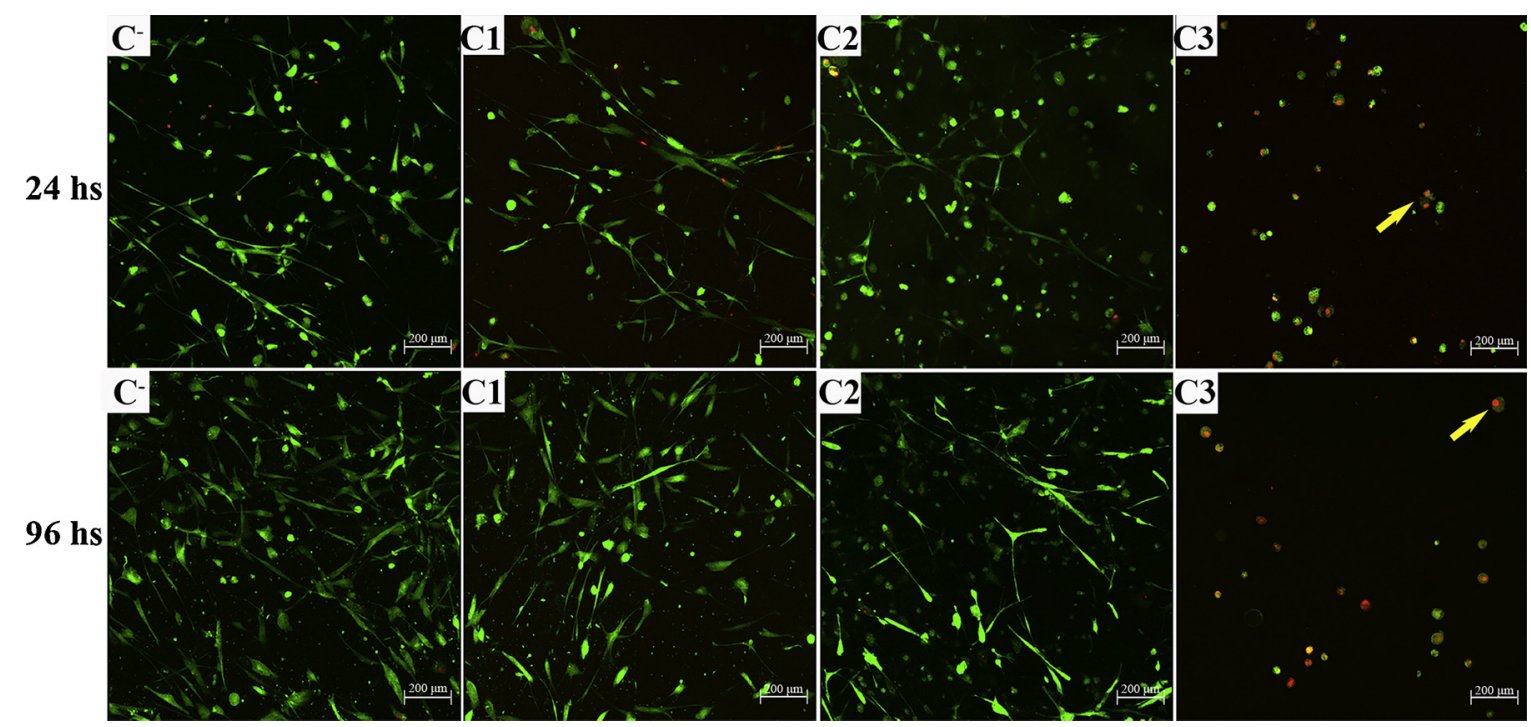

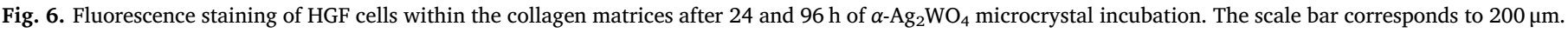
(For interpretation of the references to colour in this figure legend, the reader is referred to the web version of this article.) 
A
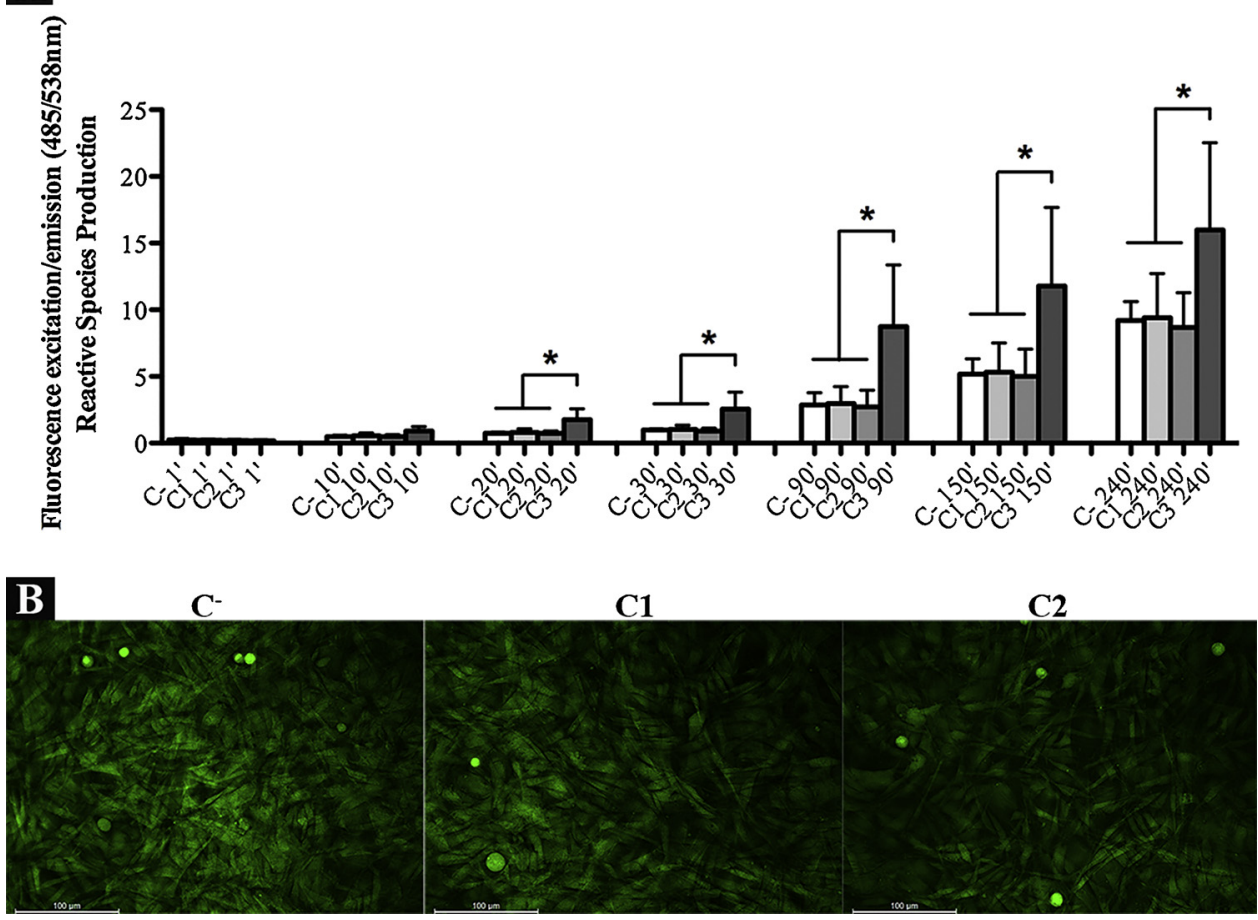

Fig. 7. Effect of $\alpha-\mathrm{Ag}_{2} \mathrm{WO}_{4}$ microcrystals on ROS generation in the HGF cells over time. A) The statistical significance of the increase in ROS production was measured according to a one-way analysis of variance (ANOVA) with a Tukey's post hoc test using Graph-Pad Prism version 5.0c. Data are shown as the mean \pm SD $(n=8)$, and *p $<0.05$ was considered statistically significant. B) Fluorescence microscopy-induced ROS production in HGF cells after $10 \mathrm{~min}$ of microcrystal incubation.

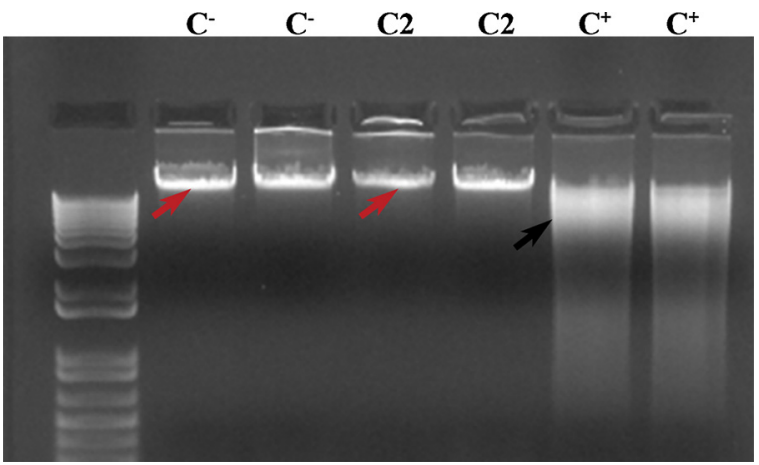

Fig. 8. Agarose gel electrophoreses pattern revealing DNA fragments in the positive control. $\alpha-\mathrm{Ag}_{2} \mathrm{WO}_{4}$ microcrystals at the MFC did not affect the DNA integrity in HGF cells. The images are representative of duplicate experiments. (For interpretation of the references to colour in this figure legend, the reader is referred to the web version of this article.)

$[28,39,40]$. With the scientific advancements in this field, the emergence of health applications has highlighted one of the most important questions about cell behavior in response to this novel agent. A fundamental concern in the biomedical purpose is the harmful silver interaction with mammalian cells [50]. The range of antimicrobial silver concentration related to a significant reduction in cell viability has been reported to be around $1-10 \mu \mathrm{g} / \mathrm{mL}$ after $24 \mathrm{~h}$ of incubation [51,52]. Importantly, our results clearly showed that the uniform size and shape distribution of $\alpha-\mathrm{Ag}_{2} \mathrm{WO}_{4}$ in our target concentration of $7.81 \mu \mathrm{g} / \mathrm{mL}$, containing $0.033 \mu \mathrm{mol} / \mathrm{mL}$ of silver, did not affect the proliferation or morphology of fibroblast cells, even after $24 \mathrm{~h}$ of exposure to the microcrystals. The non-cytotoxic effect was also confirmed by SEM analyses. A colorimetric assay revealed that the microcrystals interfered with cell proliferation only at a concentration that was ten-fold higher than the target concentration.

Since $\alpha-\mathrm{Ag}_{2} \mathrm{WO}_{4}$ microcrystals did not interfere with fibroblast cell proliferation, we examined whether this novel material could inhibit tissue repair under long-term exposure. As a convenient model system for wound healing, we used an in vitro 3D collagen matrix that mimics the in vivo cellular environment to improve the understanding of the cytotoxicity of antimicrobial agents [53-55]. During tissue repair, as a natural consequence of the wound healing process, fibroblast-derived cells decrease the size of the wound via collagen contraction [56,57]. Based on these biological principles, we demonstrated that the microcrystal composition at the MFC did not injure the fibroblast cells and did not affect the 3D collagen contraction in the first $24 \mathrm{~h}$. To further examine the wound healing process and the toxic effects of $\alpha-\mathrm{Ag}_{2} \mathrm{WO}_{4}$, we extended the exposure time to $96 \mathrm{~h}$. Consistent with the morphological results, the quantitative data clearly indicated that the desired concentration did not reduce the normal mitochondrial activity, thus revealing no difference among the $\mathrm{C} 2$ and $\mathrm{C} 1$ concentrations and untreated cells. In contrast to the monolayer cell culture approach in which microcrystals are added only after monolayer formation (ISO 10993-5), during collagen matrix construction, the microcrystals are suspended within the collagen solution prior to gelation. Hence, it is evident that toxic substances affect the cell contraction over the first hours of incubation. Fluorescent labeling confirmed that $\alpha-\mathrm{Ag}_{2} \mathrm{WO}_{4}$, at the MFC, had no effect on the cell proliferation within 3D collagen matrices, even under a long microcrystal exposure time. The images clearly show live cells when in contact with the C1 and C2 concentrations, as represented by green fluorescence due to the covalent couples between the succinimidyl ester group of CFSE and the free amines inside the cells [58]. In contrast, the C3 concentration directly affected the propagation of fibroblast cells and caused their death. PI is not permeable through the cell membrane, and it binds to DNA of cells. The loss of membrane integrity, identified as the presence of very high microcrystal concentrations, was determined by red fluorescence.

We next evaluated whether the level of ROS generated by C2 microcrystal concentrations was closely related to the level of ROS production obtained from untreated cells. Under normal conditions, the overall ROS by-products are involved in physiological regulation and coordinate the crucial cellular processes by gene expression and protein translation [59]. The HFG cells in contact with $\mathrm{C} 1$ and $\mathrm{C} 2$ demonstrated a similar intensity of fluorescence to that shown by the negative controls, indicating that the $\alpha-\mathrm{Ag}_{2} \mathrm{WO}_{4}$ microcrystal concentrations were 
not capable of disturbing the intracellular ROS levels that are normally produced by the cells. However, a harmful ROS effect was observed for the C3 microcrystal concentrations in contact with HGF cells. The increased level of intracellular ROS production can modify cell components and cause membrane degradation. Hence, once HGF cells lose membrane integrity, the DCFH probe does not undergo hydrolysis, and no fluorescence is detected by microscopy [27]. The absence of fluorescence in cells in contact with the $\mathrm{C} 3$ concentration reveals the strong cytotoxic effect of this level of $\alpha-\mathrm{Ag}_{2} \mathrm{WO}_{4}$, which damages the cells, even during a short incubation period. We then measured the products of DCFH outside the cells over time and confirmed that independent of the time point, the data were consistent in exhibiting unsafe ROS levels only to C3 concentrations of the $\alpha-\mathrm{Ag}_{2} \mathrm{WO}_{4}$ microcrystals. Our study considered a broad range of oxidants produced by the cells. However, DCFH as a non-specific probe possesses several methodology limitations $[27,59,60]$, thus requiring complementary approaches to support the findings and improve the data reliability. The imbalance in the ROS signaling may strongly affect the cell fate, whereby the overproduction of ROS directly influences cell metabolism and integrity $[61,62]$. Since there is substantial evidence that moderate levels of ROS can impair DNA integrity $[63,64]$, we demonstrated that the ROS generated under C2 exposure did not damage the DNA in the fibroblast cells. In response to harmful oxidative stress, the DNA damage appears fragmented in the gel, as observed for C3. However, the mechanisms by which $\alpha-\mathrm{Ag}_{2} \mathrm{WO}_{4}$ microcrystals at the highest concentrations induce DNA damage were not investigated. These findings provide valuable information about this novel material and encourage continued efforts to gain a better understanding of the potential effects of $\alpha-\mathrm{Ag}_{2} \mathrm{WO}_{4}$.

\section{Conclusion}

In conclusion, we demonstrated that the $\alpha-\mathrm{Ag}_{2} \mathrm{WO}_{4}$ microcrystals were non-cytotoxic against human gingival cells during a period that was long enough to measure the hazard potential. Notably, these properties were maintained over time in fibroblast cells in the 3D collagen model, which is representative of a tissue repair condition. The material suspension did not affect the fibroblast cell interactions. These results provide a significant outlook and inspire additional testing for future biological applications of $\alpha-\mathrm{Ag}_{2} \mathrm{WO}_{4}$.

\section{Conflict of interest}

The authors declare no conflicts of interest.

\section{Acknowledgements}

This work was supported by the São Paulo Research Foundation (FAPESP) [grant \#2015/25124-0 and CDMF: 2013/07296-2]. Erica Dorigatti de Avila was supported by FAPESP [grant \#2015/03567-7], Natali Lisette Haro Chávez was supported by the National Council of Technological and Scientific Development (CNPq) [grant \#163196/ 2015-0] and Camila Cristina de Foggi was supported by FAPESP [grant \#2015/03654-7].

\section{Appendix A. Supplementary data}

Supplementary material related to this article can be found, in the online version, at doi:https://doi.org/10.1016/j.colsurfb.2018.06.023.

\section{References}

[1] B.J. Paster, S.K. Boches, J.L. Galvin, R.E. Ericson, C.N. Lau, V.A. Levanos, A. Sahasrabudhe, F.E. Dewhirst, Bacterial diversity in human subgingival plaque, J. Bacteriol. 183 (2001) 3770-3783.

[2] E. Martori, R. Ayuso-Montero, J. Martinez-Gomis, M. Vinas, M. Peraire, Risk factors for denture-related oral mucosal lesions in a geriatric population, J. Prosthet. Dent. 111 (2014) 273-279.
[3] P.E. Kolenbrander, R.J. Palmer Jr., S. Periasamy, N.S. Jakubovics, Oral multispecies biofilm development and the key role of cell-cell distance, Nat. Rev. Microbiol. 8 (2010) 471-480

[4] M. Saaby, E. Karring, S. Schou, F. Isidor, Factors influencing severity of peri-implantitis, Clin. Oral Implants Res. 27 (2016) 7-12.

[5] J. Xiao, M.I. Klein, M.L. Falsetta, B. Lu, C.M. Delahunty, J.R. Yates 3rd, A. Heydorn, $\mathrm{H}$. Koo, The exopolysaccharide matrix modulates the interaction between 3D architecture and virulence of a mixed-species oral biofilm, PLoS Pathog. 8 (2012) e1002623.

[6] B. Pihlstrom, Treatment of periodontitis: key principles include removing subgingival bacterial deposits; providing a local environment and education to support good home care; providing regular professional maintenance, J. Periodontol. 85 (2014) 655-656.

[7] K. Jepsen, S. Jepsen, Antibiotics/antimicrobials: systemic and local administration in the therapy of mild to moderately advanced periodontitis, Periodontology 2000 71 (2016) 82-112.

[8] V.M. D'Costa, C.E. King, L. Kalan, M. Morar, W.W. Sung, C. Schwarz, D. Froese, G. Zazula, F. Calmels, R. Debruyne, G.B. Golding, H.N. Poinar, G.D. Wright, Antibiotic resistance is ancient, Nature 477 (2011) 457-461.

[9] Y. Xie, J. Chen, J. He, X. Miao, M. Xu, X. Wu, B. Xu, L. Yu, W. Zhang, Antimicrobial resistance and prevalence of resistance genes of obligate anaerobes isolated from periodontal abscesses, J. Periodontol. 85 (2014) 327-334.

[10] M.H. Kollef, Broad-spectrum antimicrobials and the treatment of serious bacterial infections: getting it right up front, Clin. Infect. Dis. 47 (Suppl. 1) (2008) S3-13.

[11] M. Paul, V. Shani, E. Muchtar, G. Kariv, E. Robenshtok, L. Leibovici, Systematic review and meta-analysis of the efficacy of appropriate empiric antibiotic therapy for sepsis, Antimicrob. Agents Chemother. 54 (2010) 4851-4863.

[12] https://http://www.cdc.gov/fungal/antifungal-resistance.html.

[13] R.P. Allaker, The use of nanoparticles to control oral biofilm formation, J. Dent. Res. 89 (2010) 1175-1186.

[14] P.V. AshaRani, G. Low Kah Mun, M.P. Hande, S. Valiyaveettil, Cytotoxicity and genotoxicity of silver nanoparticles in human cells, ACS Nano 3 (2009) 279-290.

[15] H. Qin, H. Cao, Y. Zhao, C. Zhu, T. Cheng, Q. Wang, X. Peng, M. Cheng, J. Wang, G. Jin, Y. Jiang, X. Zhang, X. Liu, P.K. Chu, In vitro and in vivo anti-biofilm effects of silver nanoparticles immobilized on titanium, Biomaterials 35 (2014) 9114-9125.

[16] H.S. Sharma, S. Hussain, J. Schlager, S.F. Ali, A. Sharma, Influence of nanoparticles on blood-brain barrier permeability and brain edema formation in rats, Acta Neurochir. Suppl. 106 (2010) 359-364.

[17] W. Yang, C. Shen, Q. Ji, H. An, J. Wang, Q. Liu, Z. Zhang, Food storage material silver nanoparticles interfere with DNA replication fidelity and bind with DNA, Nanotechnology 20 (2009) 085102.

[18] C.B. Thompson, Apoptosis in the pathogenesis and treatment of disease, Science 267 (1995) 1456-1462.

[19] N. El Yamani, A.R. Collins, E. Runden-Pran, L.M. Fjellsbo, S. Shaposhnikov, S. Zielonddiny, M. Dusinska, In vitro genotoxicity testing of four reference metal nanomaterials, titanium dioxide, zinc oxide, cerium oxide and silver: towards reliable hazard assessment, Mutagenesis 32 (2017) 117-126.

[20] I.C. Chen, I.L. Hsiao, H.C. Lin, C.H. Wu, C.Y. Chuang, Y.J. Huang, Influence of silver and titanium dioxide nanoparticles on in vitro blood-brain barrier permeability, Environ. Toxicol. Pharmacol. 47 (2016) 108-118.

[21] V.M. Longo, C.C. De Foggi, M.M. Ferrer, A.F. Gouveia, R.S. Andre, W. Avansi, C.E. Vergani, A.L. Machado, J. Andres, L.S. Cavalcante, A.C. Hernandes, E. Longo, Potentiated electron transference in alpha-Ag2WO4 microcrystals with Ag nanofilaments as microbial agent, J. Phys. Chem. A 118 (2014) 5769-5778.

[22] M.T. Fabbro, C.C. Foggi, L.P. Santos, L. Gracia, A. Perrin, C. Perrin, C.E. Vergani, A.L. Machado, J. Andres, E. Cordoncillo, E. Longo, Synthesis, antifungal evaluation and optical properties of silver molybdate microcrystals in different solvents: a combined experimental and theoretical study, Dalton Trans. 45 (2016) 10736-10743.

[23] P.M. Skarstad, S. Geller, (W4o16)8-polyion in high-temperature modification of silver tungstate, Mater. Res. Bull. 10 (1975) 791-799.

[24] D. Stone, J. Liu, D.P. Singh, C. Muratore, A.A. Voevodin, S. Mishra, C. Rebholz, Q. Ge, S.M. Aouadi, Layered atomic structures of double oxides for low shear strength at high temperatures, Scr. Mater. 62 (2010) 735-738.

[25] C.C. de Foggi, M.T. Fabbro, C.E. Vergani, J. Andres, E. Longo, A.L. Machado, Tuning the morphological, optical, and antimicrobial properties of $\alpha$-Ag2WO4 microcrystals using different solvents, Cryst. Growth Des. 17 (2017) 6239-6246.

[26] M.G. Bonini, C. Rota, A. Tomasi, R.P. Mason, The oxidation of 2',7'-dichlorofluorescin to reactive oxygen species: a self-fulfilling prophesy? Free Radic. Biol. Med. 40 (2006) 968-975.

[27] B. Kalyanaraman, V. Darley-Usmar, K.J. Davies, P.A. Dennery, H.J. Forman, M.B. Grisham, G.E. Mann, K. Moore, L.J. Roberts 2nd, H. Ischiropoulos, Measuring reactive oxygen and nitrogen species with fluorescent probes: challenges and limitations, Free Radic. Biol. Med. 52 (2012) 1-6.

[28] T. Kruk, K. Szczepanowicz, D. Kregiel, L. Szyk-Warszynska, P. Warszynski, Nanostructured multilayer polyelectrolyte films with silver nanoparticles as antibacterial coatings, Colloids Surf. B: Biointerfaces 137 (2016) 158-166.

[29] B. Guan, H. Wang, R. Xu, G. Zheng, J. Yang, Z. Liu, M. Cao, M. Wu, J. Song, N. Li, T. Li, Q. Cai, X. Yang, Y. Li, X. Zhang, Establishing antibacterial multilayer films on the surface of direct metal laser sintered titanium primed with phase-transited lysozyme, Sci. Rep. 6 (2016) 36408.

[30] Z. Liu, Y. Zhu, X. Liu, K.W. Yeung, S. Wu, Construction of poly (vinyl alcohol)/poly (lactide-glycolide acid)/vancomycin nanoparticles on titanium for enhancing the surface self-antibacterial activity and cytocompatibility, Colloids Surf. B: Biointerfaces 151 (2017) 165-177. 
[31] J. Andres, L. Gracia, P. Gonzalez-Navarrete, V.M. Longo, W. Avansi Jr., D.P. Volanti, M.M. Ferrer, P.S. Lemos, F.A. La Porta, A.C. Hernandes, E. Longo, Structural and electronic analysis of the atomic scale nucleation of $\mathrm{Ag}$ on alphaAg2WO4 induced by electron irradiation, Sci. Rep. 4 (2014) 5391.

[32] L.S. Cavalcante, M.A. Almeida, W. Avansi Jr., R.L. Tranquilin, E. Longo, N.C. Batista, V.R. Mastelaro, M.S. Li, Cluster coordination and photoluminescence properties of alpha-Ag2WO4 microcrystals, Inorg. Chem. 51 (2012) 10675-10687.

[33] J.W. Xu, Z.D. Gao, K. Han, Y. Liu, Y.Y. Song, Synthesis of magnetically separable $\mathrm{Ag} 3 \mathrm{PO} 4 / \mathrm{TiO} / \mathrm{Fe} 3 \mathrm{O} 4$ heterostructure with enhanced photocatalytic performance under visible light for photoinactivation of bacteria, ACS Appl. Mater. Interfaces 6 (2014) 15122-15131.

[34] M. Yamanaka, K. Hara, J. Kudo, Bactericidal actions of a silver ion solution on Escherichia coli, studied by energy-filtering transmission electron microscopy and proteomic analysis, Appl. Environ. Microbiol. 71 (2005) 7589-7593.

[35] K. Blecher Paz, A. Friedman, Nanotechnology and the diagnosis of dermatological infectious disease, J. Drugs Dermatol. 11 (2012) 846-851.

[36] R.C. de Oliveira, C.C. de Foggi, M.M. Teixeira, M.D. da Silva, M. Assis, E.M. Francisco, B.N. Pimentel, P.F. Pereira, C.E. Vergani, A.L. Machado, J. Andres, L. Gracia, E. Longo, Mechanism of antibacterial activity via morphology change of alpha-AgVO3: theoretical and experimental insights, ACS Appl. Mater. Interfaces 9 (2017) 11472-11481.

[37] R.A. Roca, A.F. Gouveia, P.S. Lemos, L. Gracia, J. Andres, E. Longo, Formation of Ag nanoparticles on beta-Ag2WO4 through electron beam irradiation: a synergetic computational and experimental study, Inorg. Chem. 55 (2016) 8661-8671.

[38] M.A. San-Miguel, E.Z. da Silva, S.M. Zannetti, M. Cilense, M.T. Fabbro, L. Gracia J. Andres, E. Longo, In situ growth of Ag nanoparticles on alpha-Ag2WO4 under electron irradiation: probing the physical principles, Nanotechnology 27 (2016) 225703.

[39] M. Ahamed, M. Karns, M. Goodson, J. Rowe, S.M. Hussain, J.J. Schlager, Y. Hong, DNA damage response to different surface chemistry of silver nanoparticles in mammalian cells, Toxicol. Appl. Pharmacol. 233 (2008) 404-410.

[40] Y.C. Chen, K.P. Yu, Enhanced antimicrobial efficacy of thermal-reduced silver nanoparticles supported by titanium dioxide, Colloids Surf. B: Biointerfaces 154 (2017) 195-202.

[41] T. Finkel, Signal transduction by reactive oxygen species, J. Cell Biol. 194 (2011) $7-15$.

[42] M. Schieber, N.S. Chandel, ROS function in redox signaling and oxidative stress, Curr. Biol. 24 (2014) R453-462.

[43] Z.A. Wood, L.B. Poole, P.A. Karplus, Peroxiredoxin evolution and the regulation of hydrogen peroxide signaling, Science 300 (2003) 650-653.

[44] H. Meng, T. Xia, S. George, A.E. Nel, A predictive toxicological paradigm for the safety assessment of nanomaterials, ACS Nano 3 (2009) 1620-1627.

[45] E.R. Stadtman, B.S. Berlett, Reactive oxygen-mediated protein oxidation in aging and disease, Chem. Res. Toxicol. 10 (1997) 485-494.

[46] G. Poli, G. Leonarduzzi, F. Biasi, E. Chiarpotto, Oxidative stress and cell signalling, Curr. Med. Chem. 11 (2004) 1163-1182.

[47] H.F. Poon, V. Calabrese, G. Scapagnini, D.A. Butterfield, Free radicals and brain aging, Clin. Geriatr. Med. 20 (2004) 329-359.

[48] H. Shi, L.G. Hudson, K.J. Liu, Oxidative stress and apoptosis in metal ion-induced carcinogenesis, Free Radic. Biol. Med. 37 (2004) 582-593.

[49] R. Pillon Barcelos, L.F. Freire Royes, J. Gonzalez-Gallego, G. Bresciani, Oxidative stress and inflammation: liver responses and adaptations to acute and regular exercise, Free Radic. Res. 51 (2017) 222-236.

[50] D. McShan, P.C. Ray, H. Yu, Molecular toxicity mechanism of nanosilver, J. Food Drug Anal. 22 (2014) 116-127.

[51] S. Chernousova, M. Epple, Silver as antibacterial agent: ion, nanoparticle, and metal, Angew. Chem. Int. Ed. Engl. 52 (2013) 1636-1653.

[52] S. Galdiero, A. Falanga, M. Vitiello, M. Cantisani, V. Marra, M. Galdiero, Silver nanoparticles as potential antiviral agents, Molecules 16 (2011) 8894-8918.

[53] C. Helary, L. Ovtracht, B. Coulomb, G. Godeau, M.M. Giraud-Guille, Dense fibrillar collagen matrices: a model to study myofibroblast behaviour during wound healing, Biomaterials 27 (2006) 4443-4452.

[54] F. Grinnell, W.M. Petroll, Cell motility and mechanics in three-dimensional collagen matrices, Annu. Rev. Cell Dev. Biol. 26 (2010) 335-361.

[55] K. Wolf, S. Alexander, V. Schacht, L.M. Coussens, U.H. von Andrian, J, van Rheenen, E. Deryugina, P. Friedl, Collagen-based cell migration models in vitro and in vivo, Semin. Cell Dev. Biol. 20 (2009) 931-941.

[56] R. Higashiyama, S. Nakao, Y. Shibusawa, O. Ishikawa, T. Moro, K. Mikami, H. Fukumitsu, Y. Ueda, K. Minakawa, Y. Tabata, G. Bou-Gharios, Y. Inagaki, Differential contribution of dermal resident and bone marrow-derived cells to col lagen production during wound healing and fibrogenesis in mice, J. Invest. Dermatol. 131 (2011) 529-536.

[57] J.J. Tomasek, G. Gabbiani, B. Hinz, C. Chaponnier, R.A. Brown, Myofibroblasts and mechano-regulation of connective tissue remodelling, Nat. Rev. Mol. Cell Biol. 3 (2002) 349-363.

[58] X.Q. Wang, X.M. Duan, L.H. Liu, Y.Q. Fang, Y. Tan, Carboxyfluorescein diacetate succinimidyl ester fluorescent dye for cell labeling, Acta Biochim. Biophys. Sin. (Shanghai) 37 (2005) 379-385.

[59] K.M. Holmstrom, T. Finkel, Cellular mechanisms and physiological consequences of redox-dependent signalling, Nat. Rev. Mol. Cell Biol. 15 (2014) 411-421.

[60] S.L. Hempel, G.R. Buettner, Y.Q. O'Malley, D.A. Wessels, D.M. Flaherty, Dihydrofluorescein diacetate is superior for detecting intracellular oxidants: comparison with 2',7'-dichlorodihydrofluorescein diacetate, 5(and 6)-carboxy-2',7'-dichlorodihydrofluorescein diacetate, and dihydrorhodamine 123, Free Radic. Biol. Med. 27 (1999) 146-159.

[61] J. Ji, V. Sharma, S. Qi, M.E. Guarch, P. Zhao, Z. Luo, W. Fan, Y. Wang, F. Mbabaali, D. Neculai, M.A. Esteban, J.D. McPherson, N.N. Batada, Antioxidant supplementation reduces genomic aberrations in human induced pluripotent stem cells, Stem Cell Rep. 2 (2014) 44-51.

[62] K. Pazmandi, Z. Agod, B.V. Kumar, A. Szabo, T. Fekete, V. Sogor, A. Veres, I. Boldogh, E. Rajnavolgyi, A. Lanyi, A. Bacsi, Oxidative modification enhances the immunostimulatory effects of extracellular mitochondrial DNA on plasmacytoid dendritic cells, Free Radic. Biol. Med. 77 (2014) 281-290.

[63] S. Alarifi, D. Ali, W. Al-Bishri, In vitro apoptotic and DNA damaging potential of nanobarium oxide, Int. J. Nanomed. 11 (2016) 249-257.

[64] A. Manke, L. Wang, Y. Rojanasakul, Mechanisms of nanoparticle-induced oxidative stress and toxicity, Biomed. Res. Int. 2013 (2013) 942916. 